\title{
Árva László
}

\section{Egy gondolat fejlódése - A gyermekfedezeti nyugdíjreform lehetôsége és szülkségessége}

\section{The Evolution of a Thought - The Opportunity and Necessity of a Child-Based Pension}

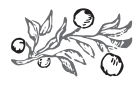

\section{Összefoglalás}

A fejlett országokban a csökkenó születésszám miatt nemcsak a nyugdíjrendszerek kerültek válságba, hanem a társadalom elöregedése a gazdaság egészséges múködését is veszélyezteti. Kérdés, hogy milyen módon lehet küzdeni a nyugdíjrendszer válsága ellen. Az elmúlt évtizedekben számos javaslat született e témában, és a következô cikkben azt kívánom a szakirodalom áttekintése, valamint statisztikai elemzések révén megvizsgálni, hogy e javaslatok közül melyek lehetnek hosszabb távon relevánsak. A hazai nyugdíjrendszer és a népesedés adatainak elemzése azt mutatta, hogy igaza volt a magyar származású Demény és a német Sinn professzoroknak, akik azt állították, hogy a gyermekvállalási kedv csökkenéséhez nagymértékben hozzájárult maga az öregségi nyugdíjrendszer általánossá válása. Végsố soron tehát az a következtetés adódik, hogy a nyugdíjrendszer válságának kezelésére a leghatékonyabb módszerként egy olyan gyermekfedezeti nyugdíjrendszer kialakítása mutatkozhat, amely nemcsak a nyugdíjrendszer gondjait orvosolná, hanem megoldást adhatna a demográfiai krízisre is. Hazánkban a Botos házaspár, Mészáros József, Banyár József, a cseh Hyzl és munkatársai, Giday András és Szegố Szilvia fejlesztette tovább ezeket a javaslatokat.

Dr. Árva LÁszLó közgazdász, az ESSCA Budapest üzleti főiskola nyugállományú professzora (laszlo.d.arva@gmail.com). 
Journal of Economic Literature (JEL) kódok: G28, H26, I13, H24, H55

Kulcsszavak: társadalombiztosítási rendszer, öregedés, gyermekfedezeti nyugdíj, demográfiai változások

\section{Summary}

Decline in the number of births in developed countries has not only put pension plans at risk, but ageing societies also jeopardise the healthy operation of the economy. How can the crisis of the pension system be combated? In the past few decades numerous proposals have been made in this issue, and on the basis of a review of the relevant literature and statistical analyses, the paper seeks to identify the proposals that may be relevant over the long term. The analysis of Hungary's pension regime and population data, performed in the article, confirmed that Professor Demény, of Hungarian extraction, and the German Professor Sinn were right when they claimed that the widespread adoption of old-age pension system has contributed to a major extent to the decline in the desire to have children. Thus, the ultimate conclusion is that the most efficient method of managing the pension crisis is the establishment of a pension scheme paid by the pensioners' children. In addition to remedying the challenges that jeopardise pension payment, such a system would also offer a solution for the current demographic crisis. In Hungary these proposals have been further elaborated by the Botos couple, József Mészáros, József Banyár, the Czech Hyzl and his colleagues, András Giday and Szilvia Szegó.

Journal of Economic Literature (JEL) codes: G28, H26, I13, H24, H55

Keywords: social security system, ageing, pension by children, demographic changes

\section{A TANULMÁNy ALAPKÉRDÉSE, MÓDSZERE ÉS HIPOTÉZISEI}

A cikkben mindenekelőtt arra a kérdésre keresek választ, hogy az elmúlt évtizedekben milyen megoldási javaslatok születtek a nyugdíjrendszert összeomlással fenyegetó demográfiai helyzet orvoslására. Kérdés az is, voltak-e ezek közt olyan javaslatok is, amelyek nemcsak a nyugdíjrendszereket kívánták megmenteni, hanem konkrét ötleteket is adtak annak érdekében, hogy a nyugdíjrendszer maga is járuljon hozzá a népesség növekedéséhez. Továbbá vizsgálandó az is, hogy Magyarországon kimutatható-e releváns összefüggés a nyugdíjrendszer és a gyermekvállalási kedv alakulása közt?

A kutatás módszertanát elsôsorban a hazai és a nemzetközi szakirodalom, illetve a rendelkezésre álló hazai statisztikák elemzése jelenti. A szakirodalom vizsgálata azért is nagyon fontos, mert a nyugdíjrendszerek napjainkban komoly belsố feszültségekkel küzdenek, és számos olyan javaslat hangzott el az elmúlt évtizedek során, amelyek megvalósításuk után - feltehetően nem biztosítanák a nyugdíjrendszer tartós múködôképességét. E javaslatok közt akad több olyan is, amely hasznosan alkalmazható, és amelyek képesek kezelni nemcsak a nyugdíjrendszer gondjait, hanem a demográfiai 
Árva László: Egy gondolat fejlödése - A gyermekfedezeti nyugdíjreform lehetôsége...

válságot is. Továbbá egy egyszerú statisztikai idôsoros elemzés révén is meg kívánom vizsgálni a nyugdíjrendszerben részt vevôk számának és a gyermekvállalási hajlandóság alakulásának összefüggését Magyarország esetében.

Cikkem egyik fố hipotézise az, hogy a nyugdíjrendszer általánossá válása jelentôsen csökkentette Magyarországon is a gyermekvállalási hajlandóságot. A másik hipotézis szerint léteznek a szakirodalomban olyan javaslatok, amelyek képesek kezelni a nyugdíjrendszer és a fejlett társadalmak elöregedésének kérdéseit. Ez a rendszer alapvetôen a gyermekfedezeti nyugdíj lenne, amely - kiegészítve további gyermeknevelést támogató intézkedésekkel - képes lehet a nyugdíjrendszer megmentésére, valamint a demográfiai válság kezelésére.

\section{A TÁrsadALOMBIZTOSítási RENDSZER ALAPJAI ${ }^{1}$}

A napjainkban létezô társadalombiztosítási rendszerek eredetileg az önkéntes magánbiztosítási rendszerekbôl fejlôdtek ki, ezért nem meglepó, hogy sokan ma is az önkéntes biztosítási modellt tekintik a társadalombiztosítás par excellence alapmodelljének. A társadalombiztosítás alrendszerei közül a következőkben csak a demográfiai válság kialakulásáért részben felelős nyugdíjrendszert fogjuk vizsgálni.

A társadalombiztosítási és azon belül a nyugdíjrendszer konkrét formája, múködése, finanszírozási módja sok helyütt történelmi örökségként alakult úgy, ahogy létrejött, és nagyon ritkán került sor arra, hogy a társadalombiztosítási rendszert vagy annak akár csak egy elemét racionálisan, a hatások sokoldalú elemzését, a gazdasági és társadalmi következményeket vizsgálva alakítanák ki. Az elméleti megalapozását illetôen ki kell emelni Samuelson ötvenes évek végén írt híres cikkét, amelyben a nyugdíjrendszer elméleti megalapozását végezte el, és amelyet később Banyár József elméleti oldalról bírált (Samuelson, 1958; illetve Banyár, 2014a).

Történelmileg Magyarország példáján keresztül is kimutatható, hogy a társadalombiztosítási rendszer általánossá válása és a csökkenô gyermekvállalás összefügg egymással. Hazánkban a mezôgazdasági népesség nyugdíjellátása gyakorlatilag a hetvenes évekre vált általánossá, az 1975. évi II. törvény egységesítő és kiterjesztő rendelkezései alapján. Csak ekkorra vált a népesség nagy része (saját vagy hozzátartozói jogon) biztosítottá a nyugdíjrendszerben. Látható ugyanakkor, hogy éppen ezt követôen került sor azokra a kedvezôtlen demográfiai változásokra is, amelyek következtében a népesség tartósan csökkenni kezdett.

Sajnos nem állnak rendelkezésre olyan hivatalos és megbízható statisztikai adatok, amelyek megadnák, hogy egy adott idószakban hazánkban a munkaképes korú népesség hány százaléka részesült kötelezô, állami nyugellátásban, de a jogszabályok elemzése révén becsléseket lehet tenni erre. 
1. ábra: Az aktív magyarországi népességból a hatályos jogszabályok által, kötelezố módon elöírt nyugdíellátásban részesülők aránya (\%)

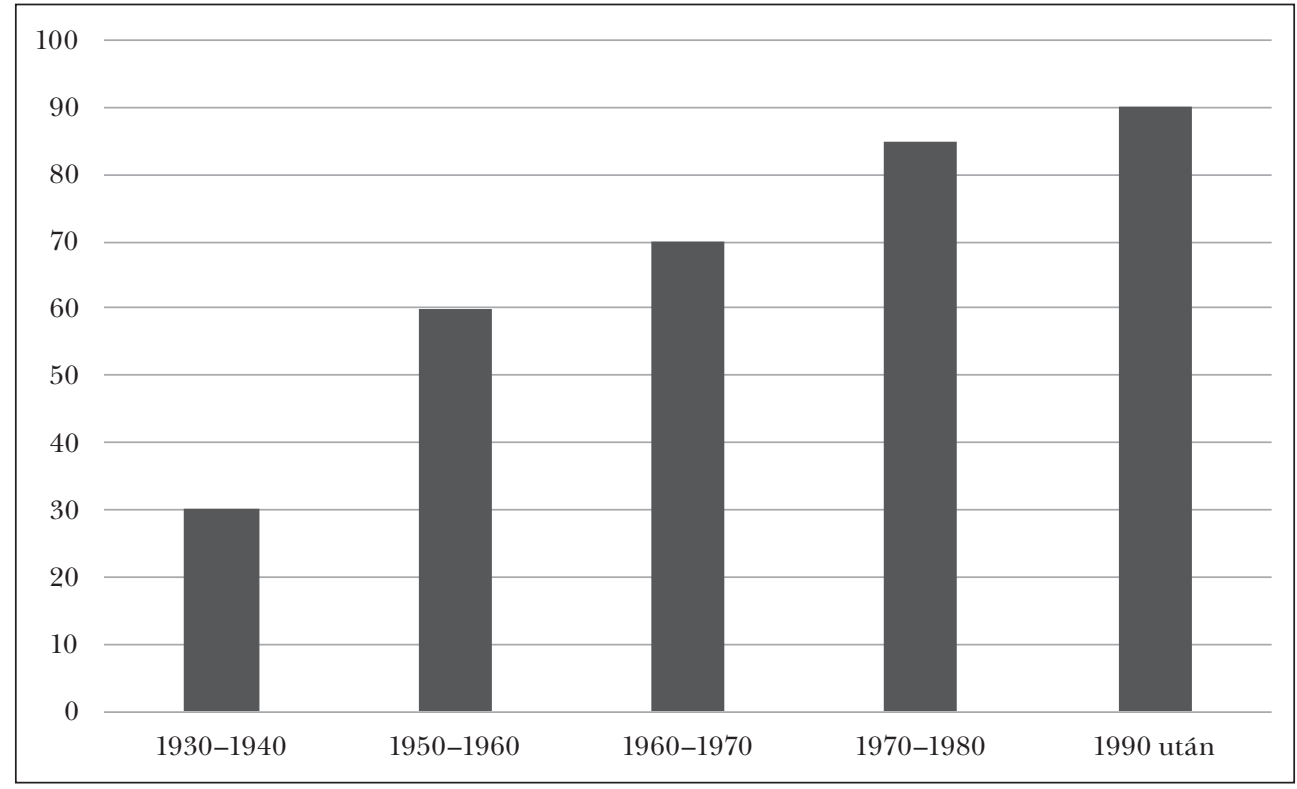

Forrás: Saját becslés a releváns jogszabályok elemzése alapján

2. ábra: A természetes szaporodás és fogyás alakulása hazánkban

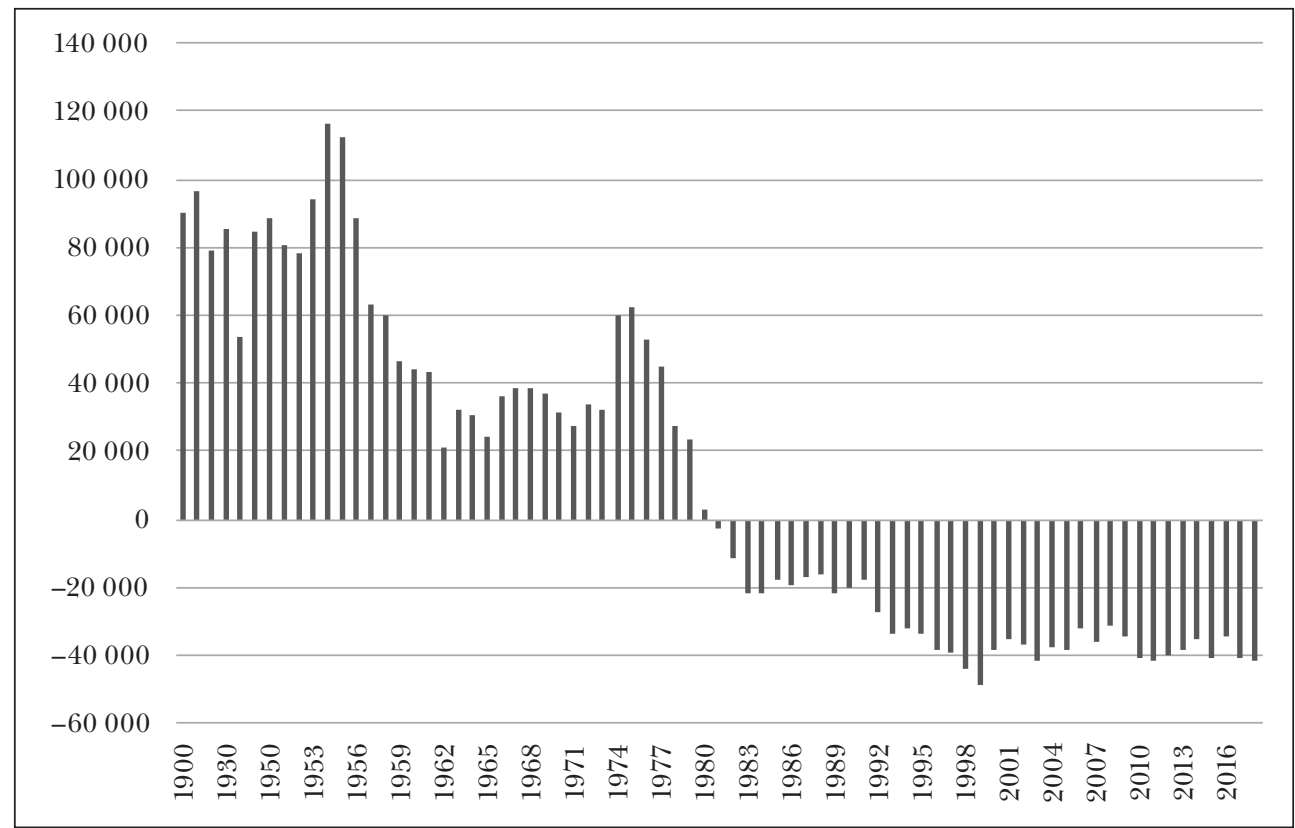

Forrás: wwww.ksh.hu/docs/hun/xstadat/xstadat_hosszu/h_wdsd001a.html 
Árva László: Egy gondolat fejlödése - A gyermekfedezeti nyugdíjreform lehetôsége...

3. ábra: A teljes termékenységi arány alakulása hazánkban

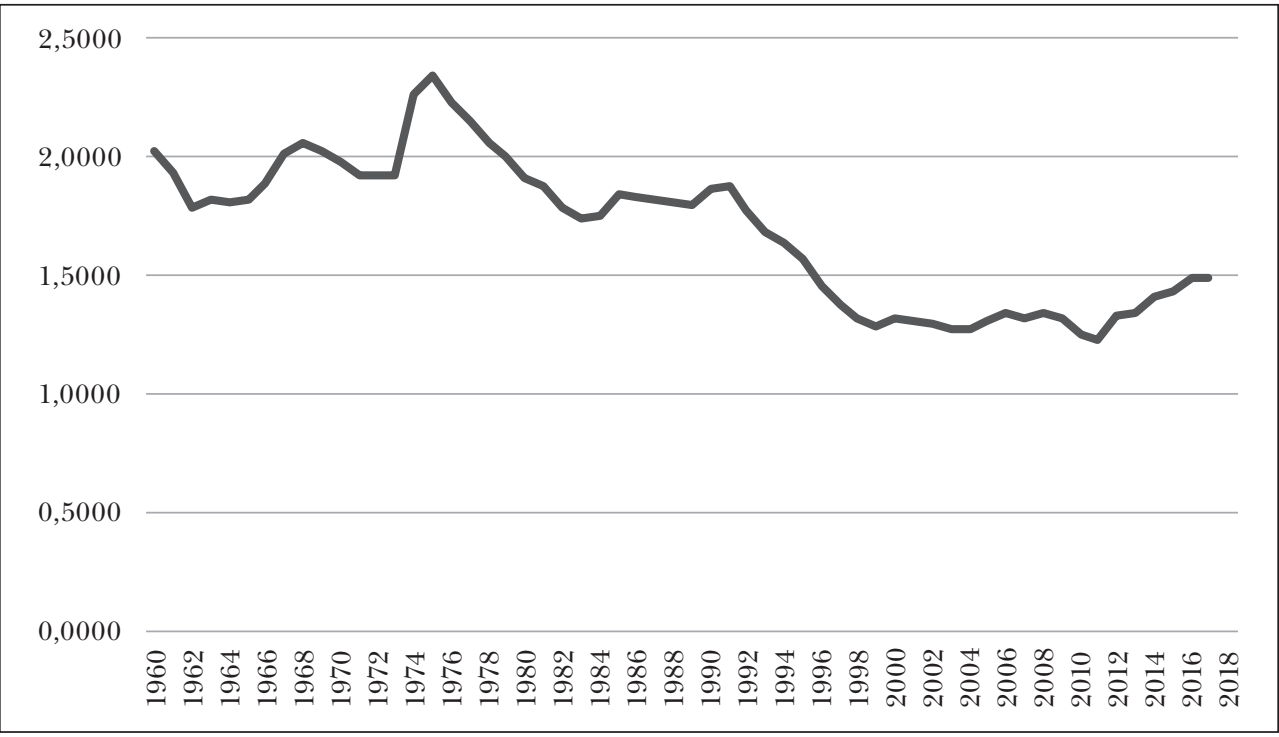

Forrás: Saját készítés

4. ábra: Az élveszületés és halálozás alakulása hazánkban

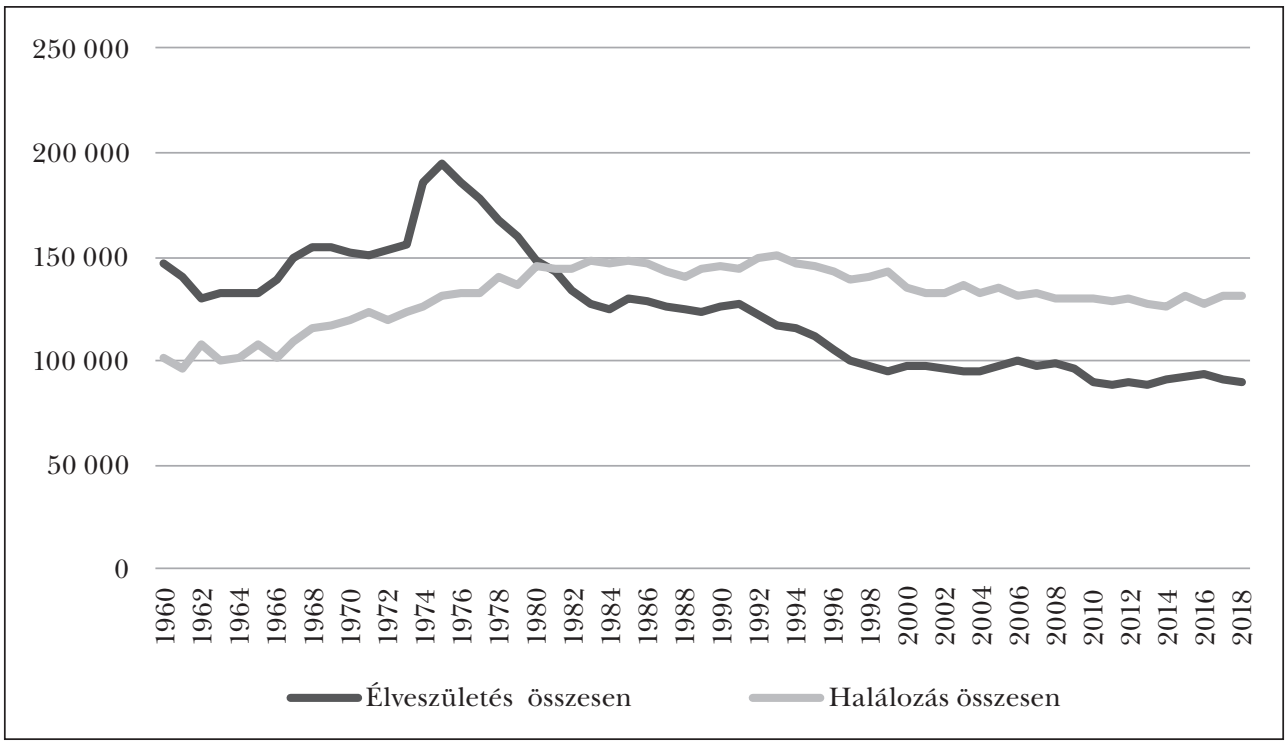

Forrás: www.ksh.hu/docs/hun/xstadat/xstadat_hosszu/h_wdsd001b.html

Az adatokból látható, hogy hazánkban a teljes termékenységi mutató a század második felében, pontosabban a hatvanas évektől egyre inkább elmaradt a népesség reprodukálását lehetôvé tevô 2,1-es értéktôl, és ennek eredményeként a nyolcvanas 
évek elejétől a népesség folyamatosan csökken. A magyar nyugdíjrendszer és a magyar népességszaporodás adatai alapján jól látni, hogy a nyugdíjrendszerben való részvétel és a születési hajlandóság időben párhuzamosan alakult. A nyugdíjrendszer általánossá válása Magyarországon is a gyermekvállalási hajlandóság csökkenését eredményezte, és látható, hogy amint a hetvenes évekre gyakorlatilag általánossá vált a nyugdíjígérvény, nagyjából éppen akkorra következett be erôteljes demográfiai visszaesés is. ${ }^{2}$

\section{A FEJLETT ORSZÁGOK DEMOGRÁFiAi VÁLSÁGÁNAK KIALAKULÁSA,} ILLETVE ANNAK OKAI

A fejlett országok nyugdíjrendszerei végül is különösebb problémák nélkül múködtek, amíg a népesség folyamatosan növekedett, egészen a második világháború utáni évekig, de aztán a demográfiai apály miatt az összeomlás közelébe jutottak.

Amíg a gyermek alapvetô gazdasági és érzelmi értéket jelentett az embereknek, és a születésszabályozás kényelmes módszerei még nem terjedtek el széles körben, addig a demográfiai növekedés is fennmaradt, és a nyugdíjrendszerek is jól múködtek. Az elsố valóban hatékony fogamzásgátló tabletták a hatvanas évek elején jelentek meg a világban. A demográfiai apály okai közt a hormonális fogamzásgátlás mellett rendszerint elsôsorban az úgynevezett posztmodern értékrendszert szokták említeni, de talán a legalaposabb és a legmeggyôzoobb elemzést Hans-Werner Sinn, a Müncheni Egyetem pénzügyi tanszékének professzora adta meg még a huszadik század végén. Az elsô cikket e témában 1998-ban írta (Sinn, 1998), ahol a felosztó-kirovó nyugdíjrendszert hibáztatta a demográfiai válságért. Az elemzésben késôbb továbblépett, és azt írta, hogy az általánossá váló nyugdíjrendszer, valamint a széleskörúen elérhetô fogamzásgátlási lehetôségek, illetve a gyermeknevelés növekvô költségei együttesen eredményezték az úgynevezett DINK families, vagyis a „double income, no kids” családok, azaz a gyermektelen, kétkeresó családok megjelenését (Sinn, 2005:2-3). ${ }^{3}$

Sinn professzor szerint az államilag garantált, általános és kötelezô nyugdíj miatt a gyermekvállalás már nem volt szükséges feltétele az idôskori ellátásnak, hiszen az idôs emberek akkor is kaptak nyugdíjat, ha egyáltalán nem voltak gyermekeik. Korábban az idôskori ellátást nemcsak mint mezôgazdasági munkaerô biztosították a felnevelt gyermekek, hanem azáltal is, hogy eltartották és ellátták idôskorú szüleiket. Ha valakinek nem voltak gyermekei, az éhenhalás idôs korában szinte garantált volt, hacsak nem tett félre jelentôs pénzvagyont a késôi éveire. Az általános, garantált nyugdíjrendszer mindezt egy csapásra megváltoztatta, és ezért írta Sinn professzor, hogy a fejlett országok demográfiai gondjaiért elsôsorban az általánossá vált, az emberek idôskori ellátását gyermekek nélkül is biztosító nyugdíjrendszer a felelős (Sinn, 2004c). Ez egy sajátos potyautas-mentalitást eredményezett, amikor az emberek meg tudták spórolni a gyermekek felnevelésének költségeit azáltal, hogy abban reménykedtek, a garantált nyugdíjrendszer révén úgyis megfelelő jövedelmekhez juthatnak időskorukban.

A 20. század végén, a 21. század elején a fejlett országok egyik legnagyobb gondja a népesség folyamatos csökkenése volt, miközben a szegény országokban a népesség éppen ellenkezôleg, hihetetlenül gyors ütemben növekszik. Ezt a statisztika is jól mutatja: 
Árva László: Egy gondolat fejlődése - A gyermekfedezeti nyugdíjreform lehetôsége...

míg 1969-ben, azaz ötven évvel ezelőtt a világ népessége még csak három és fél milliárd fô volt, addig 2019-re már megközelítette a nyolcmilliárdot. Ugyanezen idô alatt Európában a népesség csak 14\%-kal növekedett, és ez a csekély növekedés is elsôsorban a bevándorlásnak volt köszönhető, mivel a nyolcvanas évektôl kezdve a kontinens népessége csökkenni kezdett. A világ leggyorsabban növekvố régiója Afrika volt, ahol ötven év alatt a népesség több mint háromszorosára nôtt, de Latin-Amerikában és Ázsiában is több mint duplájára emelkedett. A rendelkezésre álló adatokból világosan látszik, hogy napjainkban a termékenységi ráta egyetlen fejlett európai országban sem éri el a lakosság újratermeléséhez szükséges értéket, és a népesség minden európai országban - kisebb-nagyobb mértékben - csökken. ${ }^{4}$ Hasonló folyamatok zajlottak le hazánkban is.

A fejlett országokra jellemzô okok mellett egyéb hatások is a nyugdíjrendszer válsága irányában hatottak Magyarországon. Ilyen tényezô volt az 1990-es rendszerváltás nyomán kialakult munkanélküliség sajátos kezelése, ami szintén hozzájárult az aktív, keresố népesség számának csökkenéséhez.

A rendszerváltást követôen Kelet-Európában, így Magyarországon is, a KGST számára termelő iparágak és vállalatok összeomlása után jelentôs munkanélküliség alakult ki, amit a hagyományos eszközökkel nem tudtak megfelelően kezelni. A tipikus „megoldás” az volt, hogy a munkájukat elveszítő dolgozók egy része korkedvezményes rokkantsági nyugdíjba vonult a kormányzat hallgatólagos támogatásával. Mivel az átmenet válsága elsôsorban olyan iparágakat sújtott, ahol a dolgozók egyébként is erôsen egészségkárosító tevékenységeket folytattak (pl. kohászok, vasmunkások, vájárok, vegyipari dolgozók stb.), a rokkantsági nyugdíjba vonuló munkások nagy része esetében tényleg voltak kimutatható egészségügyi károsodások, ezért nem volt túl nehéz a rokkantságinyugdíj-jogosultságok megindoklása.

A rokkantsági nyugellátásban részesüló emberek száma jelentôsen nôtt 1990 után. A KSH adatai szerint a kilencvenes évek elején a rokkantsági nyugdíjasok száma Magyarországon 200 ezer volt, majd a kilencvenes évek közepére ez a szám kétszeresére, 400 ezer főre ugrott. Ugyanakkor a rokkantsági nyugellátásban részesüló emberek egy része megórizte munkaképességét, és a rokkantsági nyugdíj mellett - rendszerint „feketén”, hivatalosan nem bejelentve - keresôtevékenységet folytatott. Ezek az emberek természetesen nem fizettek sem adót, sem társadalombiztosítási járulékokat a jövedelmeik után. Mindez jelentôsen csökkentette a társadalombiztosítási rendszer befizetôinek számát. További tényezô, amely elômozdította a nyugdíjrendszer magyarországi válságát, az volt, hogy a kelet-európai új EU-tagok csatlakozását követô hétéves átmeneti türelmi időszak lejártát követôen, 2011. május 1-jétől szabadon vállalhattak munkát az EU-n belül, és ezzel a lehetôséggel a magyarok elég hamar éltek is. Napjainkra már közel félmillió magyar munkavállaló dolgozik az Európai Gazdasági Térség országaiban, de pontos számukról, valamint országonkénti megoszlásukról igen nehéz pontos adatokat találni. A nehézségek egyik legfőbb oka, hogy nem kötelezô bejelenteni a külföldi munkavállalást, de a fogadó országok esetében is csak az egy évnél hosszabb, tartós munkavállalást kell regisztrálni, tehát a tükörstatisztikák sem kellóen mutatják a tényleges helyzetet. Sajnos a KSH Népességtudományi Intézete által kiadott becslések pontossága is erôsen kérdéses. 
A NYUGdíJRendszer reformJára a Világban, ILLETVE HAZÁNKBAN TETT JAVASLATOK KRITIKAI ÁTTEKINTÉSE

Az elmúlt évek során több elképzelés is született mind a világban, mind hazánkban a demográfiai krízis miatt válságba került öregségi nyugdíjrendszer finanszírozási gondjainak kiküszöbölésére. Ezek a javaslatok a következôk voltak:

1. Az értékrendszer átalakitása, meggyốzés, rábeszélés és egyéb állami PR-intézkedések. Ezen javaslatok révén meglehetôsen nehéznek látszik eredményt elérni mindaddig, amíg a gyermekvállalási hajlandóság növekedése jelentôs anyagi hátrányt okoz a családoknak. A nyugat-európai demográfiai helyzet azonban azt mutatja, hogy komoly és tartós javulás nem igazán várható a rábeszéléstôl, ameddig a meghatározó anyagi okok a gyermekvállalás elhalasztását ösztönzik.

2. A gyermekvállalás ösztönzése a családok támogatása, bölcsôde-és óvodaépitések, a nök részmunkaidős foglalkoztatásának elösegitése, családipótlék-rendszer stb. révén. Ezen módszerek segíthetnek ugyan a gyermekvállalás növelésében, de feltehetốn átütô megoldást önmagukban nem képesek adni, mivel a DINK-családok potyautas-mentalitását nem igazán képesek felülírni, amíg az alapvetố anyagi ellenösztönzốk a gyermekvállalás ellen hatnak.

3. A nyugdíjrendszer átalakítása öngondoskodáson alapuló, tókefedezeti rendszerré annak érdekében, hogy a nyugdíjak értékállósága fennmaradjon. Ez ígéretes megoldásnak túnhet, de erôsen kérdéses, hogy a tốkefedezeti rendszerben csökkenő népesség esetén lehetséges-e olyan hosszú távú beruházási lehetôségeket találni, amelyek biztosítják a nyugdíjcélú megtakarítások értékállóságát.

4. Az Európába irányuló, külsó bevándorlás elômozdítása, ezzel a negatív demográfiai hatások kiküszöbölése. Ez érdekes javaslatnak és elsô látásra megszívlelendô ötletnek is túnhet. Csak az a gond, hogy miként Sinn professzor azt kiszámolta (Sinn, 2004a:31-32), az Európán kívülrôl érkezô, képzetlen és nyelvismerettel nem rendelkezô bevándorlók esetében valószínú, hogy az integrálásuk és megfelelô képzésük hosszabb távon többe kerülhet, mint az általuk teljesített társadalombiztosítási befizetések összege. Végsố soron tehát a bevándorlás pénzügyi egyenlege erôsen negatív is lehet. ${ }^{5}$ Ezen túlmenôen azt is meg kell fontolni, hogy az Európán kívüli bevándorlás esetében két további kérdés is felmerül: amennyiben a bevándorlók aszszimilálódnak a helyi népességhez, a korábban magas születési rátájuk valószínúleg éppúgy lecsökken a helyi népesség alacsony születési rátájának szintjére. Amennyiben azonban az asszimilációra nem kerül sor, akkor a születési ráta is magas maradhat, de elkerülhetetlenül egyéb társadalmi gondokat okozó, elkülönült gettók kialakulásával kell majd számolni. A bevándorlás elôsegítése valószínúleg azért sem lenne képes meggátolni az európai demográfiai katasztrófát, mert ahogy azt például az Európán kívüli nagyszámú bevándorlót befogadó Svédország helyzete is mutatja, ahol napjainkban a nôk termékenységi arányszáma a jelentôs bevándorlás ellenére viszonylag alacsony, 1,87 volt az Eurostat szerint 2018-ban, és a népességcsökkenés megállításához szükséges minimum 2,1-2,2 feletti arányt még sokáig nem is remélik elérni (Eurostat, 2018). 
Árva László: Egy gondolat fejlödése - A gyermekfedezeti nyugdíjreform lehetôsége...

5. A gyermekfedezeti nyugdíjrendszer különböző formáinak kidolgozása és bevezetése a gyermekvállalás elômozdítása érdekében látszik pillanatnyilag az egyetlen, hosszabb távon is múködőképes megoldásnak. A gyermekfedezeti nyugdíjrendszert az elsôk közt kidolgozó Sinn professzor szerint logikus, hogy amennyiben a nyugdíjrendszer okozta a demográfiai katasztrófát, akkor a megoldás is ott keresendô. Sinn professzor már említett cikkeiben (Sinn, 1998; 2004a; 2004b; 2004c; 2005) egy olyan összetett nyugdíjrendszert javasolt, amelyben egyszerre lenne jelen a hagyományos felosztó-kirovó (pay-as-you-go, PAYG) nyugdíj, az általa bevezetni javasolt gyermekfedezeti nyugdíj (child related pension), valamint a kötelezô magánmegtakarítási öngondoskodó (mandatory private savings) rendszere is. A javaslat központi elemét a gyermekfedezeti nyugdíj képezné, és ennek a lényege, hogy a gyermekvállalást (a gyermekek számát) figyelembe kell venni a nyugdíjban is. Nyilvánvaló azonban, hogy a gyermekfedezeti nyugdíj mellett egyidejúleg szükség van az olyan, a gyermekek felnevelését és a szülô nôk fokozatos munkába állását elősegítő, támogató egyéb intézkedésekre is, mint amilyeneket a 2 . pontban említettünk. ${ }^{6}$

\section{JELENTHET-E MEGOLDÁST A TÖKEFEDEZETI NYUGDÍJRENDSZER}

\section{A NYUGDÍJRENDSZER VÁLSÁGÁRA?}

A PAYG-rendszer mellett a nyugdíjrendszer másik, tókefedezeti formája tiszta biztosítási elven épül fel: mindenki csak annyi nyugdíjat kaphat e rendszerben idôs korában, amennyit aktív évei alatt összegyújtött. ${ }^{7}$ Eredetileg semmi különbség nem volt a közt, hogy valaki maga gyújti egy saját bankszámlán vagy tôkeszámlán a befektetéseit, vagy hogy azt egy magán- vagy állami nyugdíjalap kezeli. ${ }^{8}$ A különbség fóként annyi, hogy az elkülönített számlán levố megtakarításokat esetleg hozzáértóbben kezelik az alapok kezelői, de nyilván ezeket az alapkezelóket el is kell tartani az alapok hozadékaiból, ami kétségtelenül megdrágítja ezt a megoldást. A tőkefedezeti nyugdíjrendszert a 20. század végén a neoliberális közgazdasági forradalom során, a Világbank ajánlásait követve (World Bank, 1994) számos országban bevezették, és Latin-Amerikában Chile (1981) mellett késôbb a térség más országaiban is alkalmazták a liberális reformot, így például Peruban (1993), Kolumbiában (1994), Argentínában (1994), Uruguayban (1995), Bolíviában (1997), Mexikóban (1997) és El Salvadorban (1998). Majd ugyancsak a nyolcvanas-kilencvenes években Európában is számos elemét alkalmazták.

Ahogy azt Mitchell Orenstein, a Pennsylvaniai Egyetem tanára írta, 1981 és 2007 között több mint 30 országban cserélték fel a PAYG-nyugdíjrendszert tôkefedezeti rendszerrel. A tôkefedezeti nyugdíjrendszer alapvetôen átalakította a korábbi nyugdíjrendszer szereplőinek helyzetét: a nők és a szegényebb emberek vesztettek, a gazdagok pedig jelentôsen nyertek vele (Orenstein, 2011:68).

Annak ellenére, hogy a tókefedezeti rendszer - amit Orenstein professzor röviden „a nyugdíjrendszer privatizációjának” nevezett - negatív oldalai már a 20. század végére nyilvánvalóak voltak, ez a reformjavaslat a kormányoknál egészen a 2008-as válságig népszerú maradt. Csak 2008-ban, a nagy gazdasági válság kitörése után kezdett alábbhagyni a tôkefedezeti rendszer iránti lelkesedés, miután Alan Greenspan, a Fed 
korábbi elnöke a kongresszusban beismerte, hogy tévedett, amikor feltételezte, hogy „a bankok és más hasonló szervezetek, saját érdekeiket követve a legjobban képesek védeni befektetôik érdekeit is" (Beattie-Politi, 2008).

Orenstein kiemelte, hogy a 2008-as válság alatt a Világbank és az IMF is elfordult a nyugdíjak privatizálásától (Orenstein, 2011:72). Egyébként az Európai Unió szigorú költségvetésideficit-szabályai is a tôkefedezeti rendszer ellen hathatnak, hiszen (amint azt Magyarország esetében 2010 körül láthattuk) az EU a magánnyugdíjpénztári befizetéseket nem ismerte el állami bevételeknek, viszont az állami PAYG-rendszer (emiatt keletkezett) költségvetési támogatásait költségvetési kiadásokként számolta el, és ez az országgal szembeni túlzottdeficit-eljárást eredményezte. ${ }^{9}$ Végsố soron ez volt az egyik meghatározó oka annak, hogy a magyar kormány 2010-ben a magánnyugdíjrendszer felszámolása mellett döntött. ${ }^{10}$

Elvben úgy tûnhet, hogy a tôkefedezeti nyugdíjrendszer képes a nyugdíjrendszer összes gondját orvosolni, mivel ott mindenki a saját korábban megtakarított pénzeit veszi ki nyugdíjaskorára, tehát teljesen érdektelen, hogy hány gyermek születik az illetô országban, vagy hogy egyáltalán születnek-e ott gyermekek. Ez azért nagyon fontos, mert ha a gazdasági növekedést nem gátolja a csökkenô népességszám, akkor a tôkefedezeti rendszer megoldást jelenthet a PAYG-rendszer válságára a demográfiai apály, vagyis a csökkenô népesség idején. Ellenkezô esetben viszont nem múködhet ez a megoldás, mert ha a gazdaság összességében a népességcsökkenés nyomán lassabban növekszik, akkor a tôkefedezeti rendszerben lekötött tôkeállomány sem hozhat megfelelő hozamot.

Sajnos empirikusan nem egyértelmúen bizonyított, hogy a lakosság csökkenése hosszabb távon gátolja, vagy éppen ellenkezôleg, segíti a gazdasági növekedést, és azon keresztül a befektetési alapok hozamnövekedését. Mosolygó Zsuzsa, az ÁKK vezető közgazdásza 2011-ben a Szegedi Egyetemre benyújtott doktori értekezésében meggyőzően érvelt amellett, hogy a csökkenó népességszám esetén a megtakarítások értéke elolvad, mivel a gazdasági növekedés szükségképpen lelassul a lakosság számának csökkenése miatt. Ahogy írta: „Fontos következtetésem az, hogy a tókefedezeti nyugdíjrendszer sem kezeli önmagában jobban az elöregedés kérdését, mint a társadalombiztosítási nyugdíjrendszer" (Mosolygó, 2011:435-461). Mosolygó szerint a tőkefedezeti nyugdíjrendszer sem képes minden nehézség nélkül megórizni a megtakarítások értékét, vagy ha mégis erre törekednének, akkor mindenképpen olyan, távoli, sok esetben egzotikus, adott pillanatban gyorsan növekedô gazdaságok eszközeibe kellene fektetni a nyugdíjrendszer megtakarításait, ami jelentôsen növelné ezen befektetések kockázati kitettségét.

Ugyanakkor Japán esetében, miután a 20. század végén ${ }^{11}$ a lakosság elöregedése felgyorsult, azt nagyon gyorsan követte a gazdasági növekedés általános lelassulása is a kilencvenes évek során. ${ }^{12}$ Ugyan elméletileg elképzelhetô, hogy a munka termelékenységének növekedése kompenzálhatja a dolgozó népesség számának csökkenését, de ez egy elméleti hipotézis csupán. Léteznek ugyan a népességváltozás és a gazdasági növekedés kapcsolatára vonatkozó empirikus vizsgálatok, de a különbözô vizsgálatok rendre ellentmondanak egymásnak. ${ }^{13}$ Így például David E. Bloom, David Canning és 
Árva László: Egy gondolat fejlödése - A gyermekfedezeti nyugdíjreform lehetôsége...

Günther Fink amerikai közgazdászok 2011-es cikke szerint nagyon nagy a bizonytalanság, és csak csekély kimutatható kapcsolat van a gazdasági növekedés és a népesség változása között (Bloom-Canning-Fink, 2011:30-32). Ugyanakkor az elmúlt évtizedek során a jelentős népességnövekedés-lassulást elszenvedó Japán esetében a gazdasági növekedés lassulásáról és a népességcsökkenés témájáról Yoshino és Taghizadeh-Hesary (2015) készítettek alapos empirikus elemzést. A szerzók egyértelmúen arra a következtetésre jutottak, hogy „az elöregedô népesség és a dolgozói létszám csökkenése a legfontosabb oka a hosszú távú recessziónak Japánban” (Yoshino-Taghizadeh-Hesary, 2015:7). Acemoglu és Restrepo (2017) amerikai közgazdászok pedig éppen ellenkezôleg azt állították, hogy a technológiai haladás általában jobban növeli a gazdasági növekedést, mint ahogy a népességszám csökkenése fékezné azt.

Sajnos a napjainkban egyre gyakoribb és súlyosabb gazdasági válságok sem teremtenek kedvezô feltételeket a megtakarítások értékállóságának biztosításához. ${ }^{14}$ Ezt az ellentmondást láthatóan érzik is a tókefedezeti nyugdíjrendszer hívei is. Erre utal, hogy egyre kevesebb szót hallani komoly szerzôktôl arra vonatkozóan, hogy az egész nyugdíjrendszert át kellene állítani a tôkefedezeti rendszerre.

\section{A GYERMEKFEDEZETI NYUGDÍJRENDSZER GONDOLATÁNAK MEGJELENÉSE ÉS A MEGVALÓSÍTÁS LEHETôSÉGEI}

A rendszerváltást követôen viszonylag hamar megjelent a nemzetközi és a hazai szakirodalomban az a gondolat, hogy a csökkenó népességszám komoly gondokat tud okozni a gazdaságnak, és hogy ez a csökkenố népességszám nagyrészt a szociálpolitika következménye. Demény Pál magyar származású, de már hosszú évek óta az Egyesült Államokban tevékenykedô, neves demográfus már a 20. század végén írt a gyermekfedezeti nyugdíjrendszer fontosságáról (Demeny, 1987), majd ugyanezt a gondolatot az MTA székházában 2002. november 20-án tartott székfoglaló elôadásában is kifejtette. Ott így beszélt: „Az uralkodó európai szociálpolitika virtuálisan biztosítja a termékenységnek az egyszerú reprodukció alatt maradó színvonalát, és így az európai népesség hosszú távú fogyását” (Demény, 2005). Sajnos azonban Demény Pál szavai és írásai csak csekély figyelmet kaptak a maguk idejében, bár nagyon valószínú, hogy a késóbb megjelenô, a gyermekfedezeti nyugdíj ötletét kidolgozó hazai szakemberek egy részére komoly hatást gyakoroltak a szakember gondolatai. Demény Pál véleménye már csak azért is elsikkadt, mert hozzá köthető az úgynevezett Demény-szavazás javaslata is, ami azt jelentette (volna), hogy a jövô nemzedékek érdekeit oly módon kellene figyelembe venni, hogy azok az állampolgárok, akiknek több gyermekük van, kapjanak több szavazatot. A Demény-szavazás körül kialakult, politikailag sok esetben túlfútött viták azonban elterelték a figyelmet Demény Pál egyéb javaslatairól, mint például a nyugdíjrendszer olyan átalakításáról, amely figyelembe veszi a felnevelt gyermekek számát is.

Úgy tûnik, hogy Sinn és Demény Pál professzorok nagyjából egyidejúleg, a 20. század végén, a 21. század elsó éveiben írták le nagyon hasonló gondolataikat, ugyanakkor kétségtelen, hogy Demény professzor már a nyolcvanas évek végén megfogal- 
mazott ilyen javaslatokat. Hazánkban talán Mészáros József (2005) volt az egyik legelsô kutató, aki egyetértően hivatkozott Sinn munkáira, kiemelve, hogy lehetséges „az aktív generáció által befizetett nyugdíjjárulékok egy részének eltérítése a felnevelô szülőkhöz, beiktatva bizonyos kompenzációs mechanizmusokat” (Mészáros, 2005:448-449). Nagyon hasonló gondolatokat, javaslatokat fogalmaztak meg 2005-ben Hyzl és munkatársai (Hyzl et al., 2005) Csehországban, ugyanis ott is egyértelmúen egy gyermekfedezeti nyugdíjrendszerrôl van szó, ahol csak az kaphat nyugdíjat, akinek gyermekei vannak. Egészen pontosan azt írják: „A jövơbe való beruházás lehet pénzbeli, avagy gyermekekbe való beruházás (a nyugdíjat tekintve mind a kettőnek azonos az értéke). Beruházás nélkül nincs haszon, és a haszon arányos a beruházás méretével... Ahogy azt korábban jeleztük, amennyiben valaki nyereségre (azaz nyugdíjra) vágyik a PAYG-nyugdíjból, gyermekekkel kell rendelkeznie” (Hyzl et al., 2005:9).

Hazánkban a korábban a társadalombiztosításnál, illetve a bankfelügyeletnél komoly gyakorlati szervezőmunkát végzó Botos József és Botos Katalin, az ismert pénzügytanprofesszorok ${ }^{15}$ szintén már a kétezres évek eleje óta foglalkoztak elméleti szinten is a nyugdíjrendszerrel. Botos Katalin és Botos József alapvetôen publicisztikai jellegú cikkeikben (Botos-Botos, 2006a; 2006b) már 2006-ban arra hívták fel a figyelmet, hogy a nyugdíjrendszer reformja során vizsgálni kellene a demográfiai következményeket is. Késóbb ezt tudományos igénnyel megfogalmazott írásukban is pontosították. Véleményük szerint a nyugdíjrendszer reformja során vizsgálni kellene a demográfiai következményeket is. Ebben a cikkben a szerzók arról írtak, hogy a nyugdíjrendszer maga is felelôs a demográfiai válságért. „A közpénzügyekbe és a társadalombiztosítási rendszerekbe való alaposabb gyakorlati elmélyedés arra döbbentett rá bennünket, hogy... a tb-nek is szerepe van a gyermekvállalás csökkenésében. Megfogalmazódott bennünk egy ezt feloldó, komplex reform szükségessége, amely tizenhét-tizennyolc évvel ezelôtt még koraszülöttnek hatott, legalábbis a magyar közéletben" (Botos-Botos, 2009:286).

Ebben az anyagban ugyan még csak homályosan körvonalazódott a gyermekfedezeti nyugdíjrendszer elképzelése, de három ével késóbb, a Pénzügyi Szemle Online hasábjain megjelent, Gyermekvállalás és nyugdíjrendszer: a reform 10 alaptétele címú cikkben már konkrét javaslatokat tettek a felnevelt gyermekek figyelembevételére a nyugdíjban (Botos-Botos, 2012). Ugyanakkor a cikkben egy sok szempontot bonyolult pontrendszerrel figyelembe vevô szisztémát vázoltak fel, és talán éppen ezen bonyolultság miatt riadtak vissza a döntéshozók mind ez idáig annak bevezetésétól.

A hazai gyermekfedezeti nyugdíjreform elméleti alapjait Banyár József azzal alapozta meg, hogy meggyôzốen bírálta és cáfolta Samuelson 1958-ban megjelentetett híres nyugdíjelméletét (Banyár, 2014a). Banyár József nagyon fontos, elemzô cikkeket írt a nyugdíjrendszer elméleti kérdéseirôl, mintegy megalapozva a gyermekfedezeti nyugdíjrendszer további kidolgozását (Banyár, 2016; 2017).

A gyermekfedezeti nyugdíjrendszer gondolatának hazai fejlődése szempontjából fontosak voltak még Giday András és Szegó Szilvia hozzájárulásai is, akik nagyjából hasonló következtetésre jutottak, mint Botos József és Botos Katalin (és persze közvetetten Demény Pál és Sinn is), de fontos, hogy egy egyszerúsített, tehát könnyebben 
megvalósítható rendszert vázoltak fel. Elsôként Szegô Szilvia fogalmazta meg elképzeléseiket, abból indult ki, hogy „a mai modern nyugdíjrendszerek alig ismerik el a gyermeknevelést (a nyugdíj 1-2 százalékával). Ez hozzájárul a gyermekvállalás visszaeséséhez, ezzel a népesség öregedéséhez. Szándékunk szerint ezt korrigálná a cikkben bemutatott gyermekfedezetú juttatás az anyák nyugdíjában. Ennek forrásául döntôen a gyermekük által befizetett járulék előre determinált hányada szolgálna, amelyet szintén meghatározott számú éven keresztül kell teljesíteni. Javaslatunk - más hasonló javaslattól eltérôen - előírja, hogy a gyermekek járuljanak hozzá járulékaikkal a nyugdíjalaphoz, ami feltétele annak, hogy a gyermekek után ne csak nyugdíjkövetelés jöjjön létre, hanem annak forrása is... Ennek kivitelezéséhez pedig egy olyan modellt dolgoztunk ki hazai demográfiai és államháztartási feltételekhez igazítva, amelyben a nôi nyugdíjkiadás mintegy egynegyedét gyermekfedezetú juttatásként kapnák meg az anyák foglalkoztatott gyermekeik után” (Szegő, 2011:419).

Az eredeti koncepció tehát:

- gyakorlatilag csak a nók (anyák) nyugdíjában vette volna figyelembe a gyerekeket;

- a gyermekek számát és a gyermekek foglalkoztatottságát is figyelembe kívánta venni;

- ezen túl a gyermekekkel nem rendelkezô nók számára is juttatott volna kompenzációt.

Giday és Szegó késôbbi írásaikban ${ }^{16}$ finomították álláspontjukat, és a Corvinus Egyetemen 2012-ben tartott nyugdíj-konferencián már hajlottak arra, hogy egyrészt tovább egyszerúsítsék a rendszert, másrészt azt javasolták, hogy a családanyák mellett az édesapák is részesüljenek a gyermekek áldásaiból a nyugdíjrendszeren keresztül is.

A Botos házaspárhoz képest a Giday-Szegô-elképzelés lényege az volt, hogy a Botosék által javasolt összetett pontrendszer helyett a gyermekek társadalombiztosítási befizetéseivel korrigálják a szülők nyugdíját. Ezt a javaslatot - éppen a kidolgozottsága és viszonylagos egyszerúsége miatt - relatíve gyorsan, jelentôsebb érdekek sérelme nélkül be lehetne vezetni. Természetesen az ördög itt is (mint mindig) a részletekben rejlik: azok a házaspárok, akik egészségi okokból kénytelenek lemondani a gyermekvállalásról, mindenképpen rosszabbul járnak, de ebben az esetben az örökbefogadás lehet a járható út.

\section{ÖSSZEFOGLALÁS ÉS KONKLÚZIÓK}

Láttuk, hogy Magyarország esetében a nyugdíjrendszer elterjedése és a gyermekvállalási hajlandóság csökkenése párhuzamosan következett be, tehát ezzel az elsô hipotézisemet igazolva láthatjuk. Ez összecseng azzal, hogy a 2000-es év táján mind a világban, mind hazánkban több kutató ráébredt arra, hogy a hagyományos nyugdíjrendszer alapvetően járul hozzá a gyermekvállalás csökkenéséhez, mivel ebben az esetben nem kell beruházni az „emberi tókébe”, vagyis nem kell gyermeket nevelni, hogy azok majd időskorukra eltartsák az embereket. Egy tipikus free-rider, potyautas-mentalitás alakult ki, aminek komoly és rendkívül káros demográfiai következményei lettek. 
A nyugdíjrendszer válságára vonatkozóan adott javaslatok közül, úgy vélem, sikerült igazolni, hogy csak a gyermekfedezeti nyugdíjrendszer képes hosszabb távon tartós megoldást adni a nyugdíjrendszer pénzügyi válságára és a demográfiai válságra. A gyermekfedezeti nyugdíjrendszer nemcsak a német Sinn professzor nevéhez köthetô, hanem feltehetôen mások, mint például Demény Pál professzor is közel ugyanakkor, a 21. század elsô éveiben, rájöttek erre. Hazánkban pár évvel késôbb jó néhány kutató, szakember tett konkrét javaslatokat arra vonatkozóan, miként lehetne a nyugdíjrendszer gyermekvállalás-ellenes élét csillapítani, és a nyugdíjrendszer révén is ösztönözni a gyermekvállalást. Ezzel a második hipotézist is igazoltnak tekintem.

Ma még nem világos, mennyi és mikor tud megvalósulni ezekból a - politikailag kétségtelenül kényes - javaslatokból, de abban a szakértók rendre egyetértenek, hogy a könnyebbik út, vagyis a magas termékenységú területekrôl az alacsony termékenységú térségekbe irányuló bevándorlás támogatása hosszabb távon egyrészt valószínúleg elég drága, másrészt egy idő után a bevándorlók termékenységi mutatói a helyi alacsony szintre süllyednek, tehát hosszú távú megoldást nem lehet elérni az Európán kívüli bevándorlással. Hasonlóképpen, a befektetések hozamainak előre nem látható, szélsôséges hullámzásai miatt sem valószínú, hogy a tókefedezeti nyugdíjrendszerek bevezetése képes lenne hosszú távon megoldani a demográfiai hullámvölgy okozta problémákat a nyugdíjrendszerben.

\section{JEGYZETEK}

1 Ebben a cikkben elsôsorban a demográfiai válság megoldására irányuló javaslatokat igyekszem tárgyalni, és nem kívánom részletesen elemezni a nyugdíjrendszer kialakulásának és fejlôdésének történetét, illetve bemutatni azokat a vitákat, amelyek erre vonatkozóan zajlottak. A nyugdíjrendszerek történetérôl számos kiváló anyag áll rendelkezésre, többek között Banyár József és Mészáros József (Banyár-Mészáros, 2003; Banyár, 2017), Gál Róbert Iván (1996; 2003), illetve Németh György (2008; 2009) összegzô munkái.

2 Módszertanilag ugyan az idôsorok azonos irányú alakulása még nem bizonyítja egyértelmúen, hogy a nyugdíj általánossá válása váltotta ki a születésszám csökkenését hazánkban, mindenesetre jelzi az összefüggés meglétét. Sajnos a nagyon hiányos és eléggé megbízhatatlan becslések alapján generált adatok önmagukban nemigen tesznek lehetôvé pontosabb ökonometriai elemzéseket.

3 Természetesen elképzelhetố volt az is, hogy valaki idôskorára vagyont igyekezett felhalmozni, de ennél sokkal általánosabb és egyszerúbb volt nagyszámú gyermeket nevelni, mintegy biztosítékként az idôs napokra.

4 https://www.ksh.hu/docs/hun/eurostat_tablak/tabl/tsdde220.html.

5 Természetesen mindez nem vonatkozik azokra az emberekre, akiknek szokásaik, értékrendszerük, anyanyelvük, képzettségi szintjük közel áll a helyi lakosságéhoz. Minél kisebb a különbség a bevándorlók és a helyi népesség között, annál inkább múködhet ez a megoldás.

6 Késôbb Sinn professzor Martin Werdinggel dolgozott együtt, és elemezte ezt a kérdést (lásd pl. Werding, 2014).

7 Ebben az esetben teljesen irreleváns, hogy a magánnyugdíjalapok független vagy egy adott munkaadó vállalathoz kapcsolódó „vállalati alapok” formájában múködnek, mert a lényeg abban van, hogy nem a többiek befizetései, hanem saját korábbi betétjeinek a hozama fedezi az illetố biztosított nyugdíját: ez tulajdonképpen nem más, mint egy magántôkealap, amelyból azonban nem egy összegben, hanem havi járadékok (azaz nyugdíj) formájában veszi ki a biztosított a hozamot. Persze ez bizonyos rizikót jelenthet a tôkealapoknak is, hiszen nem igazán lehet tudni, hogy az egyes emberek meddig élnek, ezért vannak 


\section{Árva László: Egy gondolat fejlödése - A gyermekfedezeti nyugdíjreform lehetösége...}

ezeknek az alapoknak olyan biztosításmatematikus szakemberei, akik ezeket a becsléseket képesek megtenni.

8 A valóságban persze nagy jelentôsége lehet annak, hogy egy adott rendszert miként alakítottak ki, erre vonatkozóan Banyár József elemzései adhatnak érdekes betekintést.

9 A 1997-es nyugdíjreform óta a magánnyugdíjrendszer bevezetését követôen, a magánnyugdíjba történố befizetések miatt hiány keletkezett az állami nyugdíjkasszában, amit az állami költségvetés támogatással volt kénytelen kipótolni. Ez természetesen nagy lyukat ütött a költségvetésben, és annak hiányát jelentôsen megnövelte.

10 Ugyanakkor más országok esetében az EU-ban nem vették ilyen szigorúan ezt a szabályozást.

11 Japán lakossága ugyan csak 2011 után kezdett ténylegesen csökkenni, a népszaporulat már a nyolcvanas évekre erôsen lelassult, és a lakosság erősen elöregedett, miután a várható élettartam folyamatosan növekedett.

12 Bár feltehetốen annak voltak egyéb okai is, mint például az Egyesült Államok harca a piacaikat ellepố japán termékek ellen.

13 A népességszám és a gazdasági növekedés közti összefüggések elemzése már csak azért sem egyszerû, mert rendszerint hiányoznak a megbízható, végig azonos metodológiával készített, hosszú távú gazdasági adatok. Erre vonatkozóan lásd pl. www.measuringworth.com/.

14 Az egyre gyakoribb és súlyosabb gazdasági válságokra vonatkozóan érdekes elemzést adott Mérô László 2014-ben írt könyvében (Mérô, 2014).

15 A rendszerváltást követô idôszak után mindketten a Pázmány Péter Katolikus Egyetem Heller Farkas Közgazdaságtudományi Intézetének professzorai voltak.

16 Giday és Szegô késôbb a Pénzügyi Szemlében, illetve a Polgári Szemlében megjelent cikkeikben fejtették ki részletesen a javaslatukat. A logikájuk nagyon hasonlított Botos József és Botos Katalin elképzeléseihez, de a kifejtés során egy egyszerúbb, nem pontrendszerre, hanem jórészt automatikus elemekre alapozott rendszert körvonalaztak (Giday, 2011; Szegó, 2011).

\section{FELHASZNÁLT IRODALOM}

Acemoglu, Daron - Restrepo, Pascual (2017): Secular Stagnation? The Effect of Aging on Economic Growth in the Age of Automation. NBER Working Paper, No. 23077, http://dx.doi.org/10.2139/ssrn.2899142.

Andorkó Imre (2013): A magyar nyugdíjrendszer történetének áttekintése és nyugdíjrendszer 2010-es átalakításának egyes alkotmányos tulajdonvédelemmel összefüggô kérdései. Miskolci Jogi Szemle, 8. évf., 2. sz., 92-116.

Árva, László (2018): Economic and Technical Factors Behind the Rise and Fall of Economic Globalization and Some Consequences in Hungary. A Historical Perspective. Polgári Szemle/Civic Review, Vol. 14, Special Issue, 275-289, https://doi.org/10.24307/psz.2018.0418.

Augusztinovics Mária (szerk.) (2000): Körkép reform után. Tanulmányok a nyugdíjrendszerról. Közgazdasági Szemle Alapítvány, Budapest.

Banyár József (2001): Az életpálya pénzügyi tervezése. Biztosítási Oktatási Intézet, Budapest.

Banyár József (2011): A nyugdíjreform miatti államháztartási hiány elszámolhatósága. A stabilitási és növekedési egyezmény egyes követelményeinek újragondolása. Közgazdasági Szemle, 58. évf., 7-8. sz., 666-688.

Banyár József (2014a): A modern nyugdíjrendszer kialakulásának két története. Hitelintézeti Szemle, 13. évf., 4. sz., 154-179.

Banyár, József (2014b): Consequences of Cross-Border Human Capital Transfers on National PAYG Systems. In: European Pension System. Fantasy or Reality. Report on the Conference of the Central Administration of National Pension Insurance, Budapest, 19 September.

Banyár, József (2016): Possible Reforms of Pay-As-You-Go Pension Systems. European Journal of Social Security, Vol. 18, No. 3, 286-308, https://doi.org/10.1177/138826271601800303.

Banyár, József (2017): Conflict or Fair Deal Between the Generations? Alternative Economics for Pensions. Review of Sociology, Vol. 27, No. 4, 61-82. 


\section{Polgári Szemle · 15. évfolyam 4-6. szám}

Banyár József - Gál Róbert - Mészáros József (2016): Egy gyermeknevelés-függó nyugdíjrendszer körvonalai. In: Simonovits 70. Társadalom-és természettudományi irások Arkhimédésztôl az idôskori jövedelmekig. MTA KRTK Közgazdaság-tudományi Intézet, Budapest, http://econ.core.hu/file/download/Simonovits70/10_Banyar-Gal.pdf.

Banyár József - Mészáros József (2003): Egy lehetséges és kívánatos nyugdíjrendszer. Gondolat, Budapest.

Beattie, Alan - Politi, James (2008): 'I made a mistake', admits Greenspan. Financial Times, 23 October, www.ft.com/content/aee9e3a2-a11f-11dd-82fd-000077b07658.

Bloom, David - Canning, David - Fink, Günther (2011): Implications of Population Aging for Economic Growth. NBER Working Paper, No. 16705, https://doi.org/10.3386/w16705.

Botos József - Botos Katalin (2006a): A mellényt újra kell gombolni. Polgári Szemle, 2. évf., 4. sz.

Botos József - Botos Katalin (2006b): Társadalombiztosítás és népesség. Nyugdíjkilátásaink. Élet és Tudomány, 61. évf., 13. sz., 394-397.

Botos József - Botos Katalin (2009): Az idôsödés gazdasági hatásai. Egy stratégiai jelentôségú kutatás vázlata. Magyar Tudomány, 170. évf., 3. sz., 286-294.

Botos József - Botos Katalin (2012): Gyermekvállalás és nyugdíjrendszer: a reform 10 alaptétele. Pénzügyi Szemle, október 8 .

Botos Katalin (2015): Terhes örökség. Rendszerváltozás egy pénzügypolitikus szemével. Pénzügyi Szemle, 60. évf., 4. sz., 493-502.

Demeny, Paul (1987): Re-linking Fertility Behavior and Economic Security in Old Age: A Pronatalist Reform. Population and Development Review, Vol. 13, No. 1, 128-132. https://doi.org/10.2307/1972124. Magyarul: Demény Pál (2016): A gyermekvállalás és az idôskori anyagi biztonság kapcsolatának visszaállítása. KSH Népességtudományi Kutatóintézet, Budapest.

Demény Pál (2005): Európa népességpolitikai dilemmái a 21. század kezdetén. Székfoglalók a Magyar Tudományos Akadémián. MTA, Budapest.

Demeny, Paul (2006): The Political Economy of Global Population Change, 1950-2050. Population Council, New York.

Demény Pál (2016): Népességpolitika a közjó szolgálatában. KSH Népességtudományi Kutatóintézet, Budapest.

Eurostat (2018): 4\% of EU Citizens of Working Age Live in Another EU Member State. 87/2018, https://ec.europa.eu/eurostat/documents/2995521/8926076/3-28052018-AP-EN.pdf/48c473e8-c2c1-4942-b2a45761edacda37.

Gál Róbert Iván (1996): A társadalombiztosítási programok ösztönzô hatásai. Közgazdasági Szemle, 43. évf., 2. sz., 128-140.

Gál Róbert Iván (2003): A nyugdíjrendszer termékenységi hatásai. Vizsgálati módszerek és nemzetközi kutatási eredmények. In: Gál Róbert Iván (szerk.): Apák és fiúk és unokák. Osiris, Budapest, 40-50.

Giday András (2011): Gyermekfedezetú nyugdíjelem beiktatása. Polgári Szemle, 7. évf., 4. sz.

Giday András - Árva László (2018): A méretfüggố vállalati adózás. A kkv-k megvédése a globalizáció negatív hatásaitól. Polgári Szemle, 14. évf., 1-3. sz., 180-192, https://doi.org/10.24307/psz.2018.0814.

Hujo, Katja - Rulli, Mariana (2014): The Political Economy of Pension Re-Reform in Chile and Argentina. UNRISD Research Paper, No. 2014-1, United Nations Research Institute for Social Development.

Hyzl, James et al. (2005): Penzijní reforma pro Českou republiku (Inovativní přístup). SAC Working Papers/ ŠAVŠ Pracouni texty, No. 1.

Kato, Hisakazu (2019): Can the Social Security System Be Sustained? The Japan Times, 10 January, www.japantimes.co.jp/opinion/2019/01/10/commentary/japan-commentary/can-social-security-system-sustained/.

Kovács Erzsébet (szerk.) (2012): Nyugdíjés gyermekvállalás tanulmánykötet-2012. Gondolat Kiadó, Budapest. KSH (2018a): Population by sex and age. http://www.ksh.hu/interaktiv/mstat2017/charts.html

KSH (2018b): Demográfia. English Edition. Vol. 59, No. 5, www.demografia.hu/en/teszthirek/174-demografia-english-edition-new.

Mérô László (2014): A csodák logikája. A kiszámíthatatlan tudománya. Tericum, Budapest.

Mészáros József (2005): A társadalombiztosítási nyugdíjrendszerek és a termékenység kölcsönhatása. Demográfia, 48. évf., 4. sz., 436-450. 


\section{Árva László: Egy gondolat fejlödése - A gyermekfedezeti nyugdíjreform lehetôsége...}

Minenna, Marcello (2015): The Incurable Japanese Syndrome and Europe. Social Europe, 13 December, www.socialeurope.eu/the-incurable-japanese-syndrome-and-europe.

Mosolygó Zsuzsa (2011): Az államadósság hosszú távú tendenciáiról. A kormányzati Ponzi-játék és az elöregedés hatása. Pénzügyi Szemle, 56. évf., 4. sz., 435-461.

Németh György (2008): A nyugdíjügy Magyarországon 1867-tôl 1944-ig. Kézirat, készült a Nyugdíjbiztosítási Ellenôrzô Testület megbízásából.

Németh György (2009): A nyugdíjreformról. Közgazdasági Szemle, 56. évf., 3. sz., 239-269.

Nyári János (2010): A társadalombiztosítás elvi alapjai, története és rendszere. Tanulmányi segédlet, BCE.

OECD (2015): OECD Economic Outlook. Vol. 2014/2. (No. 96) and OECD Database.

OECD (2017): Pensions at a Glance 2017. OECD.

OECD (2018a): Tax Wedge. https://data.oecd.org/tax/tax-wedge.htm.

OECD (2018b): Taxing Wages. OECD, www.oecd-ilibrary.org/taxation/taxing-wages-2018_tax_wages-2018en.

OECD (2018c): OECD Tax Database. 2018.

OECD (2019): Taxing Wages - Comparative tables. Average Tax Wedge. https://stats.oecd.org/Index. aspx?QueryId=55129, Retrieved in 2019.

Orenstein, Mitchell (2011): Pension Privatization in Crisis: Death or Rebirth of a Global Policy Trend? International Social Security Review, Vol. 64, No. 3, 65-80, https://doi.org/10.1111/j.1468-246x.2011.01403.x.

Poteraj, Jarowslaw (2008): Pension Systems in 27 EU Countries. MPRA Paper, No. 31053, https://mpra. ub.uni-muenchen.de/31053/

Samuelson, Paul (1958): An Exact Consumption-Loan Model of Interest with or without the Social Contrivance of Money. Journal of Political Economy, Vol. 66, No. 6, 467-482, http://dx.doi.org/10.1086/258100.

Simonovits András (2002): Nyugdíjrendszerek: tények és modellek. Typotext, Budapest.

Sinn, Hans-Werner (1998): The Pay-As-You-Go Pension System as a Fertility Insurance and Enforcement Device. NBER Working Paper, No. 6610.

Sinn, Hans-Werner (2004a): EU Enlargement, Migration and the New Constitution. CESifo Economic Studies, Vol. 50, No. 1367, 685-707, https://doi.org/10.1093/cesifo/50.4.685.

Sinn, Hans-Werner (2004b): Ist Deutschland noch zu retten? Econ Verlag, München.

Sinn, Hans-Werner (2004c): The Pay-As-You-Go Pension System As Fertility Insurance and an Enforcement Device. Journal of Public Economics, https://doi.org/10.1016/s0047-2727(03)00015-x.

Sinn, Hans-Werner (2005): Europe's Demographic Deficit. A Plea for a Child Pension System. De Economist, 153, No. 1, 1-45, https://doi.org/10.1007/s10645-004-8084-1.

Stiglitz, Joseph E. (1998): More Instruments and Broader Goals. Moving Toward the Post-Washington Consensus. 1998 WIDER Annual Lecture, 7 January.

Stiglitz, Joseph - Furman, Jason (1998): Economic Consequences of Income Inequality. Proceedings - Economic Policy Symposium - Jackson Hole, Federal Reserve Bank of Kansas City, 221-263.

Szabó Sándorné Csemniczki Katalin (2000): Nyugdíjrendszerünk 1929-tôl 1997-ig. In: Augusztinovics Mária (szerk.): Körkép reform után. Tanulmányok a nyugdíjrendszerrôl. Közgazdasági Szemle Alapítvány, Budapest, 2000, 28-50.

Szegô Szilvia (2011): Gyermekfedezetû juttatást a nyugdíjakban - miért és hogyan? Pénzügyi Szemle, 56. évf., 4. sz., 429-446.

Werding, Martin (2014): Familien in der Gesetzlichen Rentenversicherung. www.bertelsmann-stiftung.de/de/ publikationen/publikation/did/familien-in-der-gesetzlichen-rentenversicherung/.

World Bank (1994): Averting the Old Age Crisis. Policies to Protect the Old and Promote Growth. Oxford University Press, New York, https://doi.org/10.1596/0-8213-2970-7.

Yoshino, Naoyuki - Taghizadeh-Hesary, Farhad (2015): Causes and Remedies for Japan's Long-Lasting Recession: Lessons for the People's Republic of China. ADBI Working Paper, No. 554, https://doi. org/10.2139/ssrn.2709553. 